\title{
3 温度モデルを用いた水素 MPD スラスタの電磁流体解析*1 Numerical Simulation of a Hydrogen MPD Thruster with Temperature Nonequilibrium
}

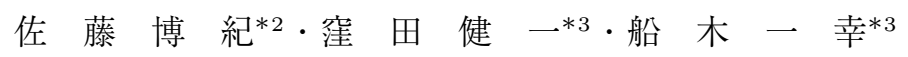 \\ Hiroki Sato, Kenichi Kubota and Ikkoh FunAKI
}

Key Words : Electric Propulsion, MPD Thruster, Hydrogen Plasma Flow, Temperature Non-Equilibrium

\begin{abstract}
Plasma flowfields and performances of an MPD thruster (MY-II thruster), which uses hydrogen as a propellant, are studied by solving axi-symmetrical two-dimensional magnetoplasmadynamic equations. The three-temperature model including the translation $T_{\mathrm{tr}}$, vibration $T_{\mathrm{vib}}$, and electron $T_{\mathrm{e}}$ temperatures is incorporated into the flow solver. When the mass flow rate $(\dot{m})$ is $1.37 \mathrm{~g} / \mathrm{s}$, there is reasonable agreement on the thrust with measured data, especially at a discharge current $\left(J_{\text {dis }}\right)$ of $7,8 \mathrm{kA}$. Under the conditions of $\dot{m}=0.4 \mathrm{~g} / \mathrm{s}$ and $J_{\text {dis }}=5 \mathrm{kA}$, the calculated thrust, specific impulse and thrust efficiency are $7.50 \mathrm{~N}, 1,911 \mathrm{~s}$ and $21.3 \%$ (without considering sheath voltage drop), respectively. The calculated flow shows a temperature nonequilibrium state $\left(T_{\mathrm{e}}=2.53 \mathrm{eV}, T_{\mathrm{vib}}=1.32 \mathrm{eV}, T_{\mathrm{tr}}=0.60 \mathrm{eV}\right)$ at the edge of the straight part, and it is found that the relaxation time between the vibration and the electron energy is equal to the characteristic time of the flow at $(z, r)=(30 \mathrm{~mm}, 20 \mathrm{~mm})$. Along the symmetrical axis, the dissociation and ionization fractions reach 1.0 (fully dissociation) and 0.2 , respectively. Because the discharge current path by the three-temperature model can explain the important feature of hydrogen MPD (current expansion to the downstream), it is concluded that the three-temperature model can reproduce the experimental results.
\end{abstract}

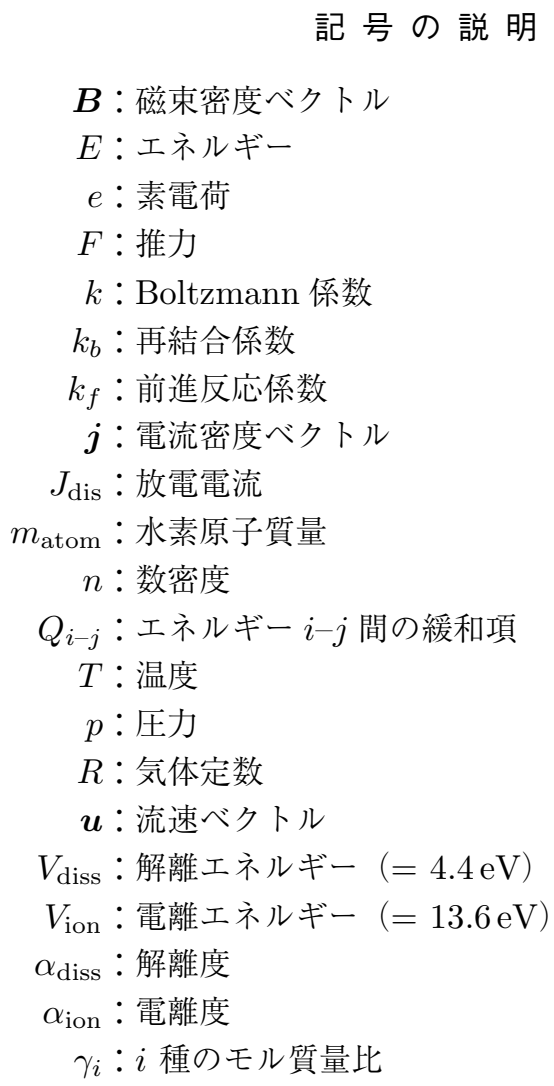

\footnotetext{
*1 (C) 2012 日本航空宇宙学会

平成 22 年 11 月 20 日原稿受付

*2 総合研究大学院大学物理科学研究科宇宙科学専攻

*3 宇宙航空研究開発機構
}

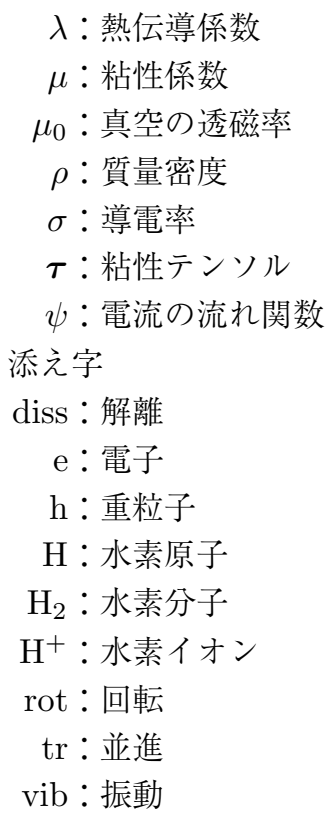

1. は じめに

MPD スラスタ (MPDT) は宇宙機用電気推進機の一種 であり, 自己誘起磁場型と外部磁場型に分類することがで きる. 本研究で扱う自己誘起磁場型 MPDT (SF-MPDT) は大電力作動に適しており, 高比推力, 高推力密度といった 特徽を持つことから, 将来の大型惑星探査機用主エンジンと して期待されている. SF-MPDT の推進効率を実用レベル まで高めるためには，推進剤の選定が重要である，上松ら1) は, 水素やアルゴンなど 11 種の推進剤について SF-MPDT 
の推進性能の比較を行い, 水素推進剤の優位性を明らかに した。この優位性は, 数多くの実験によって裏付けられて いる2). したがって，水素を推進郕とする SF-MPDT の設 計最適化が重要であるが，スラス夕形状等を実験のみで最 適化することは容易ではない。 そこで，数值解析による設 計支援が不可欠となる，過去の研究を振り返ると，水素を 推進剂とする SF-MPDT の数值解析的研究はいくつか報 告3 7) されているものの, 推進性能予測に必要な放電電圧 を正しく評価することができないなど，実験結果を十分模 擬できているとは言い難い. 放電電圧の予測精度を向上さ せるためには，SF-MPDT 放電室内のプラズマ密度，中性 粒子密度，電子温度などを正確に見積もる必要がある。

そこで, 本研究では, 水素の解離, 電離, 振動エネルギー 励起などの各種実在気体効果を考慮した物理モデルを構築 し, 同軸型SF-MPDT の数值シミュレーションを実施した. 数值シミュレーション結果と実験結果の比較により物理モ デルの妥当性を評価するとともに, 温度非平衡性と解離・ 電離反応の特性についても調べる。なお，本論文ではこれ 以降，MPDT と言えばSF-MPDT を指す。

\section{2. 計 算モ デル}

2.1 スラスタ形状 本解析で用いる同軸型スラスタ形 状を第 1 図に示す。この形状は，過去に田原らが開発した MY-II ${ }^{8)}$ をべースとしており, 推進剂は $z=0 \mathrm{~mm}$ 面から 一様に流入すると仮定した。

2.2 解析における仮定 本解析の仮定を以下に示す.

・MPDT 内部のプラズマ流を電磁流体として扱う。

・流れ場と電磁場は軸対称 2 次元とする.

・周方向の流れは生じないとする.

·SF-MPDT なので，磁場 $\boldsymbol{B}$ は自己誘起磁場の周方向成 分 $B_{\theta}$ のみ考慮する。

・スラス夕内部のレイノルズ数 $R e$ は $10^{2} \sim 10^{3}$ 程度である ため，流れ場は層流とする。

・シースは考慮しない。

·水素の反応式は第 1 表に示すものとする.

・温度評価には 3 温度モデルを採用し, $T_{\mathrm{tr}}\left(=T_{\mathrm{rot}}\right), T_{\mathrm{vib}}$, $T_{\mathrm{e}}$ を独立に扱う。

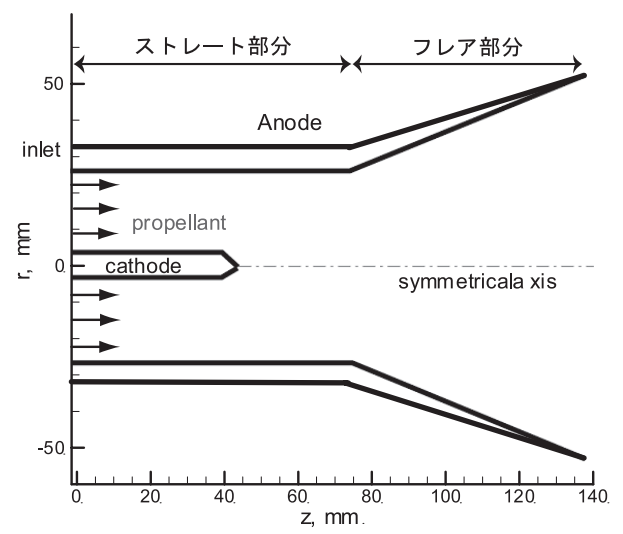

第1図ＭY-II スラスタ形状 ${ }^{8)}$
・一般化されたオームの法則において, ホール効果を考慮 する。また，電子の圧力勾配は無視する。

2.3 基礎方程式 本解析で用いた基礎方程式は，プラズ マ流体に関する保存則と, 磁場の誘導方程式から構成され る. 以下にプラズマ流体に関する質量保存則, 水素原子お よび水素イオンの質量保存則, 運動量保存則, 重粒子, 振 動 $^{9)}$, 電子エネルギーの各エネルギーの保存則を示す.

$$
\begin{aligned}
& \frac{\partial \rho}{\partial t}+\nabla \cdot(\rho \boldsymbol{u})=0 \\
& \frac{\partial \rho_{s}}{\partial t}+\nabla \cdot\left(\rho_{s} \boldsymbol{u}\right)=\dot{\rho}_{s} \quad\left(s=\mathrm{H}, \mathrm{H}^{+}\right) \\
& \frac{\partial \rho \boldsymbol{u}}{\partial t}+\nabla \cdot(\rho \boldsymbol{u} \boldsymbol{u}+p \boldsymbol{I})=\boldsymbol{j} \times \boldsymbol{B}+\nabla \cdot \boldsymbol{\tau} \\
& \frac{\partial E_{\mathrm{h}}}{\partial t}+\nabla \cdot\left[\left(E_{\mathrm{h}}+p\right) \boldsymbol{u}\right] \\
& =p_{\mathrm{e}} \nabla \cdot \boldsymbol{u}+\boldsymbol{u} \cdot(\boldsymbol{j} \times \boldsymbol{B}) \\
& +\nabla \cdot\left(\left(\lambda_{\mathrm{tr}}+\lambda_{\text {rot }}\right) \nabla T_{\mathrm{tr}}\right)+\nabla \cdot\left(\lambda_{\mathrm{vib}} \nabla T_{\mathrm{vib}}\right) \\
& +\nabla \cdot(\boldsymbol{\tau} \boldsymbol{u})-Q_{\mathrm{tr}-\mathrm{e}}+Q_{\mathrm{e}-\mathrm{vib}}-Q_{\mathrm{diss}}^{\mathrm{h}} \\
& \frac{\partial E_{\mathrm{vib}}}{\partial t}+\nabla \cdot\left[E_{\mathrm{vib}} \boldsymbol{u}\right] \\
& =\nabla \cdot\left(\lambda_{\mathrm{vib}} \nabla T_{\mathrm{vib}}\right)+Q_{\mathrm{tr}-\mathrm{vib}}+Q_{\mathrm{e}-\mathrm{vib}}-Q_{\mathrm{diss}}^{\mathrm{h}} \\
& \frac{\partial E_{\mathrm{e}}}{\partial t}+\nabla \cdot\left[E_{\mathrm{e}} \boldsymbol{u}\right]=-p_{\mathrm{e}} \nabla \cdot \boldsymbol{u}+\frac{\boldsymbol{j}^{2}}{\sigma}+\nabla \cdot\left(\lambda_{\mathrm{e}} \nabla T_{\mathrm{e}}\right) \\
& +Q_{\mathrm{tr}-\mathrm{e}}-Q_{\mathrm{e}-\mathrm{vib}}-Q_{\mathrm{diss}}^{\mathrm{e}}-Q_{\mathrm{ion}}^{\mathrm{e}}
\end{aligned}
$$

式 (4)〜 (6)の $E_{\mathrm{h}}, E_{\mathrm{vib}}, E_{\mathrm{e}}$ はそれぞれ重粒子のトータル エネルギー，振動エネルギー，電子エネルギーを表す。式 (2) の右辺は水素原子および水素イオンの生成率を表し, 以 下の式で与えられる。

$$
\begin{aligned}
\dot{\rho}_{\mathrm{H}}= & \sum_{s=1}^{4} 2\left(k_{f, s} n_{\mathrm{H}_{2}}-k_{b, s} n_{\mathrm{H}}^{2}\right) n_{s} m_{\mathrm{atom}} \\
& -\left(k_{f, s} n_{\mathrm{H}} n_{\mathrm{e}}-k_{b, s} n_{\mathrm{H}+} n_{\mathrm{e}}^{2}\right) m_{\mathrm{atom}} \\
\dot{\rho}_{\mathrm{H}^{+}}= & \left(k_{f, 5} n_{\mathrm{H}} n_{\mathrm{e}}-k_{b, 5} n_{\mathrm{H}^{+}} n_{\mathrm{e}}^{2}\right) m_{\mathrm{atom}}
\end{aligned}
$$

前進反応係数 $k_{f, s}$ は文献 10) を, 再結合係数 $k_{b, s}$ は文献 4) を参考にした。ここでの添え字 $s$ は第 1 表の反応式 No. に 対応する. 式 (3), (4) の $\boldsymbol{\tau}$ は粘性応力テンソルを表す.

$$
\boldsymbol{\tau}=\mu\left(\frac{\partial u_{i}}{\partial x_{j}}+\frac{\partial u_{j}}{\partial x_{i}}-\frac{2}{3} \delta_{i j} \frac{\partial u_{k}}{\partial x_{k}}\right)
$$

式 (4)の重粒子のトータルエネルギー $E_{\mathrm{h}}$ および式 (6) の 電子エネルギー $E_{\mathrm{e}}$ は以下のように定義される。

第 1 表 解離および電離の反応式

\begin{tabular}{ll}
\hline No. & \multicolumn{1}{c}{ 反応式 } \\
\hline & 【解離反応】 \\
1 & $\mathrm{H}_{2}+\mathrm{e}^{-} \longleftrightarrow \mathrm{H}+\mathrm{H}+\mathrm{e}^{-}$ \\
2 & $\mathrm{H}_{2}+\mathrm{H}_{2} \longleftrightarrow \mathrm{H}+\mathrm{H}+\mathrm{H}_{2}$ \\
3,4 & $\mathrm{H}_{2}+\mathrm{M} \longleftrightarrow \mathrm{H}+\mathrm{H}+\mathrm{M}\left(\mathrm{M}=\mathrm{H}, \mathrm{H}^{+}\right)$ \\
& 【電離反応】 \\
5 & $\mathrm{H}+\mathrm{e}^{-} \longleftrightarrow \mathrm{H}^{+}+\mathrm{e}^{-}+\mathrm{e}^{-}$ \\
\hline
\end{tabular}




$$
\begin{aligned}
E_{\mathrm{h}}= & E_{\mathrm{tr}}+E_{\mathrm{rot}}+E_{\mathrm{vib}}+\frac{1}{2} \rho \boldsymbol{u}^{2} \\
= & \frac{3}{2} \sum_{s \neq \mathrm{e}} \rho_{s} R_{s} T_{\mathrm{tr}}+\rho_{\mathrm{H}_{2}} R_{\mathrm{H}_{2}} T_{\mathrm{tr}} \\
& +\frac{\rho_{\mathrm{H}_{2}} R_{\mathrm{H}_{2}} \theta_{\mathrm{vib}}}{\exp \left(\theta_{\mathrm{vib}} / T_{\mathrm{vib}}\right)-1}+\frac{1}{2} \rho \boldsymbol{u}^{2} \\
E_{\mathrm{e}}= & \frac{3}{2} n_{\mathrm{e}} k T_{\mathrm{e}}=\frac{3}{2} p_{\mathrm{e}}
\end{aligned}
$$

式 (10)にて右辺第 1 項から 4 項は, それぞれ重粒子の並進工 ネルギー, 水素分子の回転エネルギー, 水素分子の振動エネ ルギー, 運動エネルギーである。また $\theta_{\mathrm{vib}}(=(U(1)-U(0)) /$ $k=6,320 \mathrm{~K})$ は振動特性温度を意味し, $U(i)$ は振動準位 $i$ におけるエネルギーである。輸送係数 $\mu, \lambda, \sigma$ と各エネ ルギー間の緩和項 $Q_{\mathrm{tr}-\mathrm{e}}, Q_{\mathrm{e}-\mathrm{vib}}, Q_{\mathrm{tr}-\mathrm{vib}}$, 重粒子どうしの 衝突解離反応によるエネルギー増減 $Q_{\mathrm{diss}}^{\mathrm{h}}$, 電子との衝突 による解離反応のエネルギー増減 $Q_{\mathrm{diss}}^{\mathrm{e}}$, 電離反応による エネルギー増減 $Q_{\text {ion }}^{\mathrm{e}}$ の式は付録に記載した.

また，磁場の誘導方程式は以下の式で与えられる。

$$
\begin{aligned}
\frac{\partial \boldsymbol{B}}{\partial t} & -\nabla \times(\boldsymbol{u} \times \boldsymbol{B}) \\
& =-\nabla \times\left\{\frac{1}{\mu_{0} \sigma} \nabla \times \boldsymbol{B}+\frac{1}{\mu_{0} e n_{\mathrm{e}}}(\nabla \times \boldsymbol{B}) \times \boldsymbol{B}\right\}
\end{aligned}
$$

以上の方程式に加え, 状態方程式 (式 (13)) とアンペール の法則（式 (14)）を用いることで方程式系は閉じる.

$$
\begin{aligned}
& p=\sum_{s \neq \mathrm{e}} n_{s} k T_{\mathrm{tr}}+n_{\mathrm{e}} k T_{\mathrm{e}} \\
& \boldsymbol{j}=\frac{1}{\mu_{0}} \nabla \times \boldsymbol{B}
\end{aligned}
$$

\section{3. 数值解析手法}

3.1 計算格子と計算領域 計算格子を第 2 図に示す。 $z$ =0〜140 mm は MPDT 内部であり, $z=140 \mathrm{~mm}$ の面 より右側はプルーム領域である。プルーム側 $z=140 \sim$ $409 \mathrm{~mm}$ の領域は長方形で, 右端ならびに上端に流出部分 がある. 格子数はスラス夕内部側で $50 \times 30$, プルーム側 で $25 \times 45$ とする。 また，軸対称を仮定しているため，対 称軸より上半面のみを計算領域とする.

3.2 数值解析手法 本解析では基礎方程式を有限体積 的に離散化して時間発展的に解く. 非粘性流束の評価には, ロバストな空間 2 次精度の TVD Lax-Friedrich スキーム を用いる. 制限関数には minmod 関数を用い, 時間積分に は 1 次精度のオイラー陽解法を用いる。

3.3 境界条件と計算条件 計算条件を第 2 表に示す. 電 流分布と流れ場に関する議論は, 電流分布の実験データが ある $\dot{m}=0.4 \mathrm{~g} / \mathrm{s}, J_{\mathrm{dis}}=5 \mathrm{kA}$ の条件で計算を行った. 推 力評価については, 質量流量 $0.4 \mathrm{~g} / \mathrm{s}$ に対する実験データが

\begin{tabular}{|c|c|}
\hline アノード壁面温度，K & $\begin{array}{l}T_{\mathrm{tr}}<1,300(=0.112 \mathrm{eV}) \\
T_{\mathrm{vib}}<1,300(=0.112 \mathrm{eV}) \\
T_{\mathrm{e}}<20,000(=1.72 \mathrm{eV})\end{array}$ \\
\hline カソード壁面温度, K & $\begin{array}{l}T_{\mathrm{tr}}<2,000(=0.172 \mathrm{eV}) \\
T_{\mathrm{vib}}<2,000(=0.172 \mathrm{eV}) \\
T_{\mathrm{e}}<25,000(=2.16 \mathrm{eV})\end{array}$ \\
\hline
\end{tabular}
存在しないため, 実験結果の存在する $\dot{m}=1.37 \mathrm{~g} / \mathrm{s}$ の条件 で計算した. 推力は入口条件に依存し, 入口における温度, 解離度，電離度をそれぞれ $2,000 \sim 6,000 \mathrm{~K}, 0.001 \sim 0.01$,

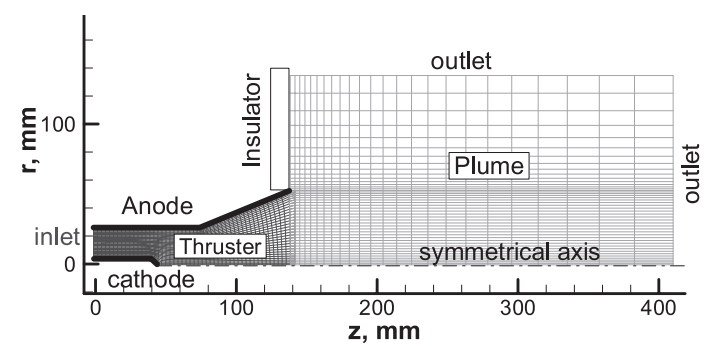

第 2 図計算格子

第 2 表 計算条件

\begin{tabular}{lcc}
\hline 推進剤 & \multicolumn{2}{c}{$\mathrm{H}_{2}$} \\
\hline 計算目的 & 流れ場評価 & 推力評価 \\
推進剤の質量流量, $\mathrm{g} / \mathrm{s}$ & 0.4 & 1.37 \\
放電電流, $\mathrm{kA}$ & 5 & $7 \sim 10$ \\
入口温度, $\mathrm{K}$ & $T_{\mathrm{tr}}=3,000(=0.259 \mathrm{eV})$ \\
& $T_{\mathrm{vib}}=5,000(=0.431 \mathrm{eV})$ \\
& $T_{\mathrm{e}}=5,000(=0.431 \mathrm{eV})$ \\
入口電離度, 一 & \multicolumn{2}{c}{0.001} \\
入口解離度, 一 & \multicolumn{2}{c}{0.005} \\
\hline
\end{tabular}

0.0005 0.005の範囲で変化させたとき最大で $12 \%$ の差が あった。そこで本計算の入口条件は，実験による推力測定 例がある $\dot{m}=1.37 \mathrm{~g} / \mathrm{s}, J_{\mathrm{dis}}=7 \mathrm{kA}$ のとき, 推力の実験 值と計算值がほぼ一致するように設定した. $\dot{m}=0.4 \mathrm{~g} / \mathrm{s}$, $J_{\mathrm{dis}}=5 \mathrm{kA}$ の計算でも同じ入口条件とした. 第 3 表に壁面 温度境界条件を示す。壁における並進温度の制限值は, 電 極材料の融点程度とした，想定した材料は，アノードは銅， カソードはタングステンである。振動温度の制限值も並進 温度と同様に設定した，また，壁における電子温度は，本 来はシースモデルから評価すべきであるが，シースは考慮 していない. 入口における半径方向の磁束密度 $B_{\theta}$,in は全 放電電流值 $J_{\mathrm{dis}}$ をもとにアンペールの法則から, 式 (15) を用いて評価する。

$$
B_{\theta, \text { in }}=-\frac{\mu_{0} J_{\mathrm{dis}}}{2 \pi r}
$$

壁面での磁束密度は, 等ポテンシャル条件から求める11). なお, 質量流量の残差が $O\left(10^{-3}\right)$ まで減少し, 推力が時 間的に一定になった場合に収束とした。このとき，質量流 量は設定值 $0.4 \mathrm{~g} / \mathrm{s}$ で $z$ 軸方向に沿って一定になっている.

\section{4. 数値計算結果と考察}

4.1 放電電流経路 最初に, 電流経路を田原らの実験結 果8) と比較する.第 3 図に電流経路を示し, 参考として以前 の 2 温度モデル $\left(T_{\mathrm{tr}}\left(=T_{\mathrm{vib}}\right), T_{\mathrm{e}}\right)$ を用いた数值計算によ る電流経路12) も示した. 2 温度モデルによる解析結果 (第 3 困 (a)) は, 第 3 図 (c) の実験結果と異なり, $z=0 \sim 75 \mathrm{~mm}$ 


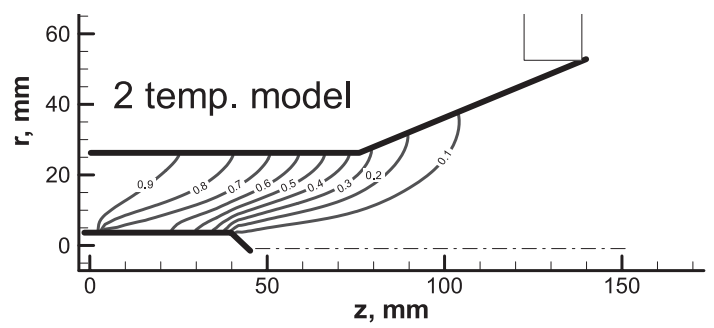

(a) 2 温度モデルによる電流経路

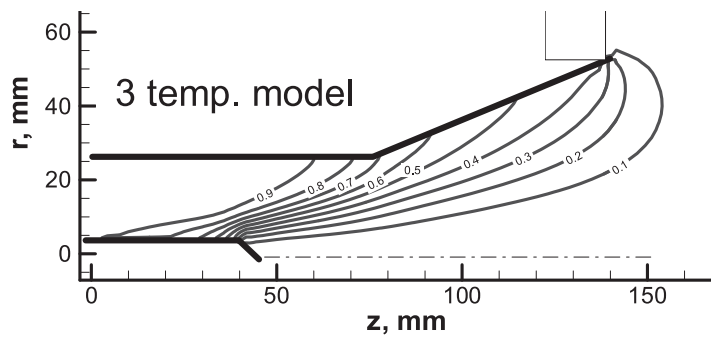

(b) 3 温度モデルによる電流経路

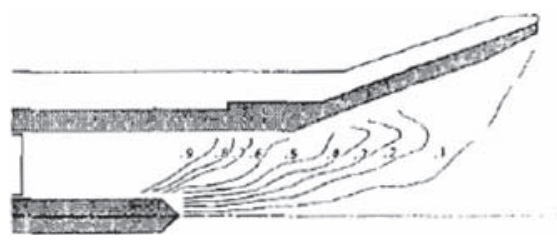

(c) 田原らによる実験結果 ${ }^{8)}$

Reprinted with permission of the American Institute of Aeronautics and Astronautics.

第 3 図 電流経路の比較 $\left(\mathrm{H}_{2}, \quad J_{\mathrm{dis}}=5 \mathrm{kA}, \dot{m}=0.4 \mathrm{~g} / \mathrm{s}\right)$ コンター線上の值は電流の流机関数 $|\psi|=\left|r B_{\theta}\right|$ であり, 2 つ のコンター線間の放電電流は一定である.

の上流部分にほとんどの電流が流れている。一方，本解析 (第 3 図 (b)， 3 温度モデル) では， $|\psi|=0.9$ の電流経路 はアノード上 $z=60 \mathrm{~mm}$ の位置に付着し，実験結果に近 い. 第 3 図 (b)に执いて, カソード上の $|\psi| \leq 0.7$ の電流 付着点はカソード先端側 $z>30 \mathrm{~mm}$ に寄っているが, 実 駼結果で見られるようなカソード先端への強い放電集中は 得られなかった。 カソード周りの実験と計算の差異に関し ては今後の検討課題である. 本解析で放電電流経路が下流 側へシフトした原因については，次節で考察する。

4.2 温度非平衡性および解離・電離特性 次に, 温度 非平衡性と解離・電離特性について調べる. 第 4 図にお いて各温度を比較すると，ほとんどの領域でプラズマ流は $T_{\mathrm{e}}>T_{\mathrm{vib}}>T_{\mathrm{tr}}$ の温度非平衡状態になっている. また，力 ソード先端 $z=45 \mathrm{~mm}$ に抒いて, 電子温度は並進温度よ りも高い. 一方, スラスタ出口付近 $z=120 \mathrm{~mm}$ より下流 側の中心軸上に扔いて, 並進温度と電子温度が等しい温度 平衡状態になっている。一方，フレア部分のアノード近傍 $(z, r)=(130 \mathrm{~mm}, 40 \mathrm{~mm})$ の周辺では, 電子温度が振動温 度や並進温度よりも高い状態になっている，本計算では陽 極表面上における振動温度, 並進温度の上限值が電子温度 に対するそれよりも低く設定してある(第 3 表参照)。しか し，アノード境界条件の 3 温度すべてを断熱条件にした場 合でも，この点の電子温度は並進温度や振動温度よりも高

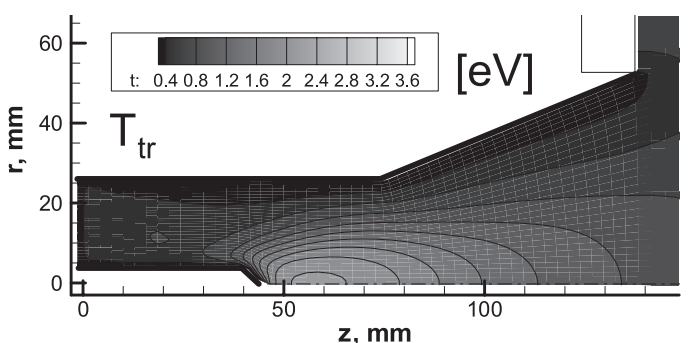

(a) 並進温度

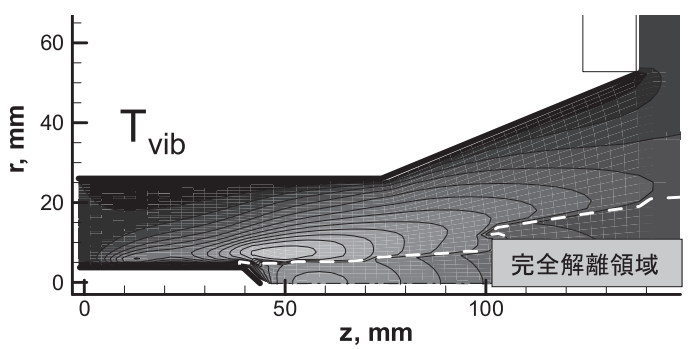

(b) 振動温度

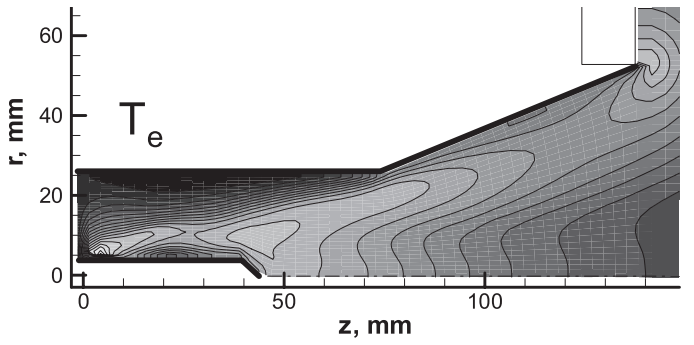

(c) 電子温度

第 4 図 各温度の分布, $\mathrm{eV}\left(\mathrm{H}_{2}, J_{\mathrm{dis}}=5 \mathrm{kA}, \dot{m}=0.4 \mathrm{~g} / \mathrm{s}\right)$ 中段：振動温度分布内の白破線より中心軸側は完全解離領域 である。この領域での $T_{\mathrm{vib}}$ は物理的に意味を持たないが，表 示の便宜上 $T_{\mathrm{tr}}$ の值を表示している.

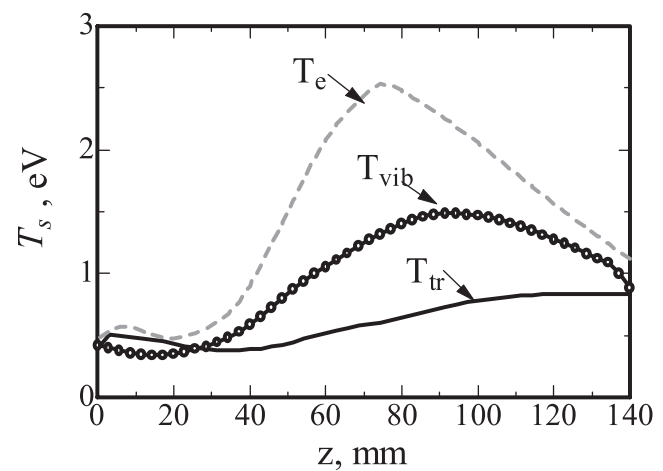

第 5 図 3 温度モデルによる各温度の $z$ 軸方向分布 $\left(r=20 \mathrm{~mm}, \mathrm{H}_{2}\right.$, $J_{\text {dis }}=5 \mathrm{kA}, \dot{m}=0.4 \mathrm{~g} / \mathrm{s}$ )

くなることが確認されているので， $T_{\mathrm{e}}>T_{\mathrm{vib}}, T_{\mathrm{tr}}$ となる 主な原因はジュール加熱だと考えられる。また，カソード 先端より下流側において, 並進温度は徐々に低下する。こ れは，フレア形状のノズルによって，熱エネルギーが空力 的推力へと変換されているためである。また，後述するよ うに，振動エネルギーと電子エネルギーは並進エネルギー へ近づくように緩和されるため, 振動温度および電子温度 も並進温度とともに徐々に低下する。 


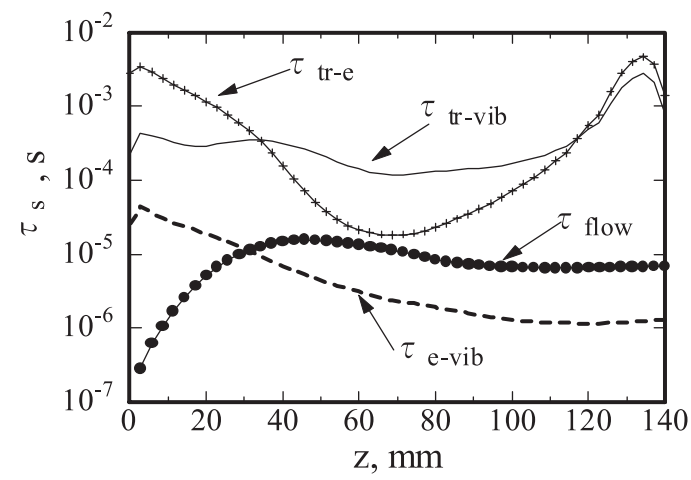

第 6 図 3 温度モデルによるエネルギー緩和特性時間と流れの特性時 間の $z$ 軸方向分布 $\left(r=20 \mathrm{~mm}, \mathrm{H}_{2}, J_{\mathrm{dis}}=5 \mathrm{kA}, \dot{m}=\right.$ $0.4 \mathrm{~g} / \mathrm{s}$ )

第 5 図に $r=20 \mathrm{~mm}$ 線上の各温度の $z$ 軸方向分布を示 す. 電子温度は $z=25 \mathrm{~mm}$ から $75 \mathrm{~mm}$ にかけて, 徐々に 増加している。電子温度の上昇後，これに遅れて並進温度 と振動温度が上昇している。これは, 放電によってまず電子 にエネルギーが与えられるためである。ストレート部端の $z=75 \mathrm{~mm}$ において, $T_{\mathrm{e}}=2.53 \mathrm{eV}, T_{\mathrm{vib}}=1.32 \mathrm{eV}, T_{\mathrm{tr}}$ $=0.60 \mathrm{eV}$ の温度非平衡状態が見られる. 振動温度は $z=$ 25 90 mm で増加し, その後, 電子温度と振動温度はそれ ぞれ $z=75 \mathrm{~mm}, 90 \mathrm{~mm}$ より下流側のフレア・ノズル部分 で低下し, スラスタ出口 $z=140 \mathrm{~mm}$ で $T_{\mathrm{tr}} \sim T_{\mathrm{vib}} \sim T_{\mathrm{e}}$ の温度平衡状態となる。この理由についてエネルギー緩和 時間の観点から考察する.

第 6 図は並進-振動間 $\tau_{\text {tr-vib }}$, 電子-振動間 $\tau_{\mathrm{e}-\mathrm{vib}}$, 電 子-並進間 $\tau_{\mathrm{tr}-\mathrm{e}}$ のエネルギー緩和時間と流れの特性時間 $\tau_{\text {flow }}=z / u(z: z$ 軸方向位置, $u$ : $z$ 軸方向流速 $)$ の軸 方向分布である。エネルギー緩和時間は, 並進と振動エネ ルギーなどの 2 つのエネルギーが平衡状態に達するまでに 要する時間を指す。その評価方法は付録 A.3「エネルギー 緩和項」を参照されたい。第 6 図より， $z=30 \mathrm{~mm}$ にて $\tau_{\text {flow }} \sim \tau_{\text {e-vib }}$ の非平衡状態になっており, 流れと振動-電 子エネルギー緩和過程はカップリングして解く必要がある. 電子-並進間の緩和時間 $\tau_{\text {tr-e }}$ は全領域で $\tau_{\text {tr-e }}>\tau_{\text {flow }}$ に なっているため，電子エネルギーと並進エネルギーの緩和 はゆっくりと進む。したがって， $z=25 \sim 75 \mathrm{~mm}$ で電子温 度 $T_{\mathrm{e}}$ はジュール加熱によって増加するが (第 5 図), 重粒 子並進温度 $T_{\mathrm{tr}}$ はすぐには増加せず $T_{\mathrm{e}}>T_{\mathrm{tr}}$ となる. $z \geq$ $75 \mathrm{~mm}$ のフレア・ノズル部分でジュール加熱は減少してい き, 電子温度も低下して, 出口 $z=140 \mathrm{~mm}$ にて $T_{\mathrm{tr}}$ は $T_{\mathrm{e}}$ とほぼ等しくなる。一方，並進一振動間の緩和時間に関 しては $\tau_{\text {tr-vib }}>\tau_{\text {flow }}$ の凍結流状態となっており, スラス 夕内部で並進一振動間のエネルギー緩和は進みにくい. 電 子-振動間のエネルギー緩和時間は, $z>30 \mathrm{~mm}$ の領域で $\tau_{\mathrm{e}-\mathrm{vib}}<\tau_{\text {flow }}$ の平衡状態になっているため, $T_{\mathrm{vib}} \sim T_{\mathrm{e}}$ に なりやすい。したがって， $z=25 \mathrm{~mm}$ で電子温度増加に追 従するように振動温度も増加し始める。そして，フレア・ ノズル部分で振動温度も電子温度とともに低下して，スラ ス夕出口で $T_{\mathrm{tr}} \sim T_{\mathrm{vib}} \sim T_{\mathrm{e}}$ の温度平衡状態となる.

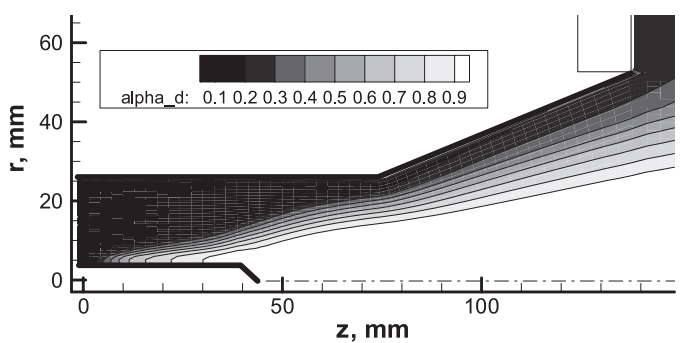

(a) 解離度分布

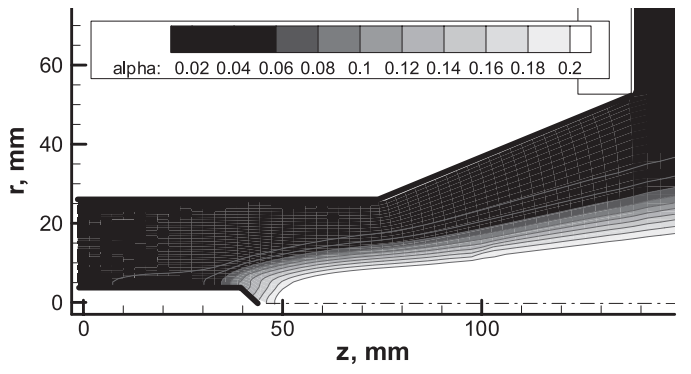

(b) 電離度分布

第 7 図 解離度および電離度分布 $\left(\mathrm{H}_{2}, J_{\mathrm{dis}}=5 \mathrm{kA}, \dot{m}=0.4 \mathrm{~g} / \mathrm{s}\right)$

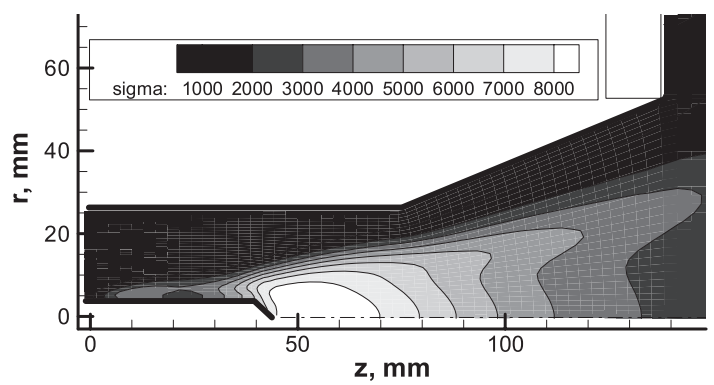

第 8 図 導電率分布, $\mathrm{S} / \mathrm{m}\left(\mathrm{H}_{2}, J_{\mathrm{dis}}=5 \mathrm{kA}, \dot{m}=0.4 \mathrm{~g} / \mathrm{s}\right)$

次に, 解離および電離特性について調べる. 解離度 $\alpha_{\mathrm{diss}}$, 電離度 $\alpha_{\text {ion }}$ は以下のように定義する.

$$
\begin{gathered}
\alpha_{\mathrm{diss}} \equiv \frac{n_{\mathrm{H}}+n_{\mathrm{H}^{+}}}{2 n_{\mathrm{H}_{2}}+n_{\mathrm{H}}+n_{\mathrm{H}^{+}}} \\
\alpha_{\mathrm{ion}} \equiv \frac{n_{\mathrm{e}}}{2 n_{\mathrm{H}_{2}}+n_{\mathrm{H}}+n_{\mathrm{H}^{+}}}
\end{gathered}
$$

第 7 図の解離度および電離度の分布において，プラズマ流が スラス夕内部を進むにつれて, 解離度, 電離度ともに徐々に 増加していることが分かる. カソード先端 $z=45 \mathrm{~mm}$ より 下流側, 中心軸付近において, 解離度は完全解離 $\left(\alpha_{\text {diss }}=1\right)$ に達する。一方，カソード先端から下流側の対称軸上におい て, 電離度は最大で 0.2 程度になるが, 完全電離 $\left(\alpha_{\mathrm{ion}}=1\right)$ には達しない。また，アノード付近の領域において，電離 度は 0.02 以下であり，ほとんど電離していない。

第 8 図に導電率の分布を示す. カソード先端 $z=45 \mathrm{~mm}$ 周辺で導電率が最大值に達している。これは，前述したよ うにカソード先端付近で電子温度と電離度が高いためであ る.このような導電率分布になることで，カソード先端よ り下流を電流が流れやすくなり, 放電電流経路はスラス夕 下流側ヘシフトしたと考えられる。 


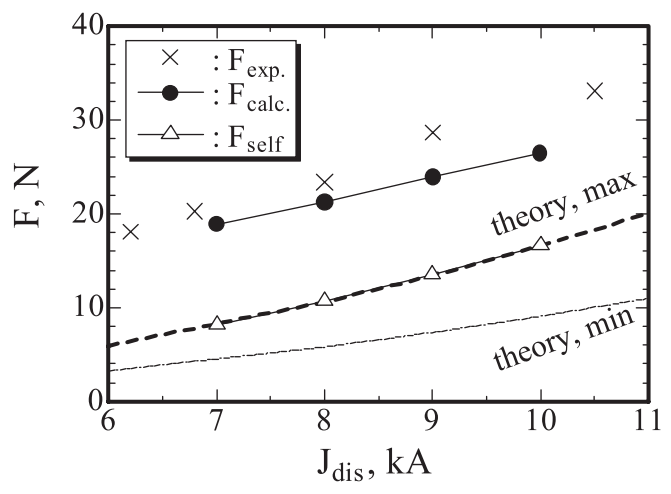

第 9 図 放電電流と推力 $\left(\mathrm{H}_{2}, \dot{m}=1.37 \mathrm{~g} / \mathrm{s}\right.$, 実験デー夕は文献 15$)$ を参照, 理論電磁推力 "theory, min", "theory, max" は $r_{\mathrm{a}} / r_{\mathrm{c}}=38.5 / 4.75$ として算出)

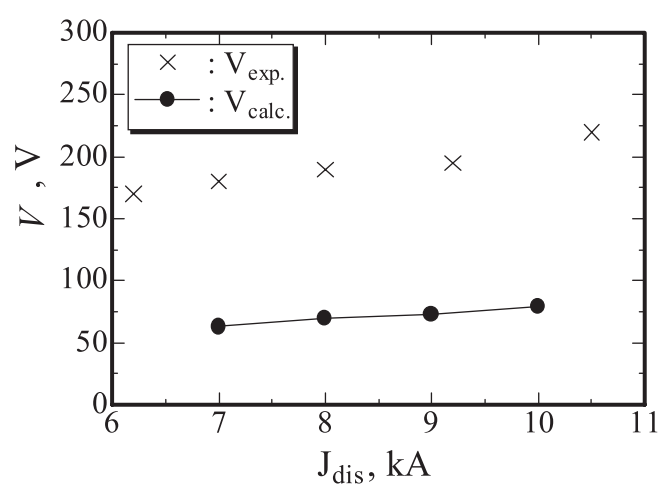

第 10 図 放電電流と放電電圧 $\left(\mathrm{H}_{2}, \dot{m}=1.37 \mathrm{~g} / \mathrm{s}\right.$, 実験デー夕は文 献 15) を参照)

4.3 数值解析による推進性能評価 数值解析による推 進性能評価を推進剤流量 $1.37 \mathrm{~g} / \mathrm{s}$ の計算結果によって示す. 推力および放電電圧の評価式は文献 11) を参照した。第 9 図は推進剤流量 $1.37 \mathrm{~g} / \mathrm{s}$ としたときの放電電流と推力の関 係を示している. 図中の $J_{\mathrm{dis}}=7,8 \mathrm{kA}$ のとき, 適切な 入口条件を設定したことで, 数值計算による推力 $F_{\text {calc. }}$ は 実験結果をほぼ再現できている．数值計算による電磁推力 $F_{\text {self }}$ は理論曲線（図中: 破線）によく一致している。一方， $J_{\text {dis }}>9 \mathrm{kA}$ のとき, $F_{\text {calc. }}$ は $F_{\text {exp. }}$ に比べて過小評価に なっている。この原因としては, すべての放電電流 $J_{\mathrm{dis}}$ に おいて同じ入口条件に設定していること（入口条件による 推力の誤差）が考えられる。

第 10 図は放電電流と放電電圧の関係を実験結果と比較 した図である。本計算結果から評価した放電電圧 $V_{\text {calc. }}$ は

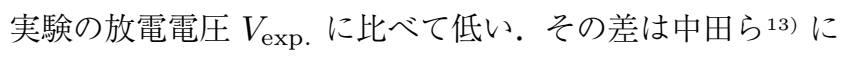
よって測定されたシース電圧約 $20 \mathrm{~V}$ （ただし推進郕はアル ゴン）を上回っている．アルゴンと水素でシース電圧が同 じとは限らないが, シース電圧が数 $10 \mathrm{~V}$ 程度であると仮定 すれば，本解析は実験に比べてバルク電圧を過小評価して いる可能性がある。この原因としては，1）イオン・中性粒 子間の速度スリップ，2）異常抵抗，3）反応モデルや導電率 モデルの違い, が考えられる. 杵淵らの実験結果 ${ }^{14)}$ ではイ オン・中性粒子間の速度スリップが観測されており, $u \times B$
第 4 表 推進性能 $\left(\mathrm{H}_{2}, \dot{m}=0.4 \mathrm{~g} / \mathrm{s}, \quad J_{\mathrm{dis}}=5 \mathrm{kA}\right)$

\begin{tabular}{lcc}
\hline & $\begin{array}{c}3 \text { 温度 } \\
\text { モデル }\end{array}$ & $\begin{array}{c}2 \text { 温度 } \\
\text { モデル }\end{array}$ \\
\hline スラスタ形状 & MY-II & MY-II \\
放電電流, $\mathrm{kA}$ & 5.0 & 5.0 \\
推力 $\mathrm{F}, \mathrm{N}$ & 7.50 & 5.26 \\
比推力, s & 1911 & 1342 \\
放電電圧, V & 66.0 & 40.2 \\
推進効率\% & 21.3 & 17.2 \\
& (シースなし) & (シースなし) \\
\hline
\end{tabular}

の逆起電力によって放電電圧が増加している可能性が示唆 されている。また，2）が生じた場合，導電率が減少して放 電電圧が増加する．3）の反応モデルは, 電子数密度分布な どを介して導電率評価にも影響する。また，導電率モデル も高精度化する必要がある。バルクプラズマのモデルに関 して，1）－3）の正確なモデリングは今後の課題である.さ らに，シースモデルの構築扔よびそれとのカップリング計 算も課題である.

前節で議論した条件（推進剂流量 $0.4 \mathrm{~g} / \mathrm{s} ， J_{\mathrm{dis}}=5 \mathrm{kA}$ ) での推進性能を第 4 表に示す. 放電電圧は以前の 2 温度モ デル12) の結果より大きな值になっている。これは第 3 図で 示したように， 3 温度モデルによる電流経路のアノードーカ ソード間距離が 2 温度モデルのときよりも長くなったため である。これに伴って投入電力が増加して空力的推力も増 えたことで, 3 温度モデルによる推力は 2 温度モデルの推 カより大きな值になっている.

\section{5. 結論}

本研究はMPDT（フレア型 MY-II 形状）の数值シミュ レーション結果と実験結果の比較により, 推進剤である水 素の解離・電離過程や振動エネルギー励起などの各種実在 気体効果を考慮した水素 MPDT のモデルの妥当性を評価 し, 温度非平衡性と解離・電離反応の特性について調べた. その結果，以下のことが明らかになった。

1）適切な入口条件を設定することで, 推進剤流量 $1.37 \mathrm{~g} / \mathrm{s}$, 放電電流 $7,8 \mathrm{kA}$ のとき, 計算による推力は実 験結果をほぼ再現できていた。推進剤流量 $0.4 \mathrm{~g} / \mathrm{s}$, 放電電 流 $5 \mathrm{kA}$ のとき (以下の結論はこの計算条件のもの), 実験 による電流経路を比較的よく再現できた。しかし, 数值計算 結果におけるカソード上の電流経路は実験ほどカソード先 端に集中しなかった。数值解析結果から評価した推進性能 は, 推力 $7.50 \mathrm{~N}$, 比推力 $1911 \mathrm{~s}$, 放電電圧 $66 \mathrm{~V}$ であった.

2）温度分布を調べたところ，ほとんどの領域で $T_{\mathrm{e}}>$ $T_{\mathrm{vib}}>T_{\mathrm{tr}}$ の温度非平衡状態であることが明らかになった. 振動-電子間のエネルギー緩和時間と流れの特性時間が同程 度の非平衡状態の領域が存在するので, 本解析のように流 れと振動一電子エネルギーの緩和過程をカップリングして解 く必要がある。

3）電子温度㧍よび電離度はカソード先端で高いため, 導 電率はカソード先端で最大值となり, 放電電流分布はスラ スタ下流側ヘシフトする。 また, 解離度は中心軸付近で 1 (完全解離) に達するが, 電離度は 1 (完全電離) には達せ 
ず，最大で 0.2 程度であった.

4) 推進剂流量 $1.37 \mathrm{~g} / \mathrm{s}$ のとき, 数值計算の放電電圧は 実験結果より低かった．数值計算による放電電圧の予測精 度向上のために, 中性粒子とイオンの速度スリップのモデ ルやシースモデルなどの導入が今後の課題である.

\section{参 考 文 献}

1) Uematsu, K., Morimoto, S. and Kuriki, K.: MPD Thruster Performance with Various Propellants, J. Spacecraft, 22 (1984), pp. 412-416.

2) Sovey, J. S. and Mantenieks, M. A.: Performance and Lifetime Assessment of Magnetoplasmadynamic Arc Thruster Technology, J. Propul. Power, 7 (1991), pp. 71-80.

3) Sumida, M. and Toki, K.: Scaling Law and Real Gas Effect of MPD Thruster, AIAA Paper-87-1066, 1987.

4) Shoji, T. and Kimura, I.: Analytical Study on the Influence of Nonequilibrium Ionization for Current Flow Pattern and Flow Field of MPD Arcjets, AIAA Paper 90-2609, 1990.

5) Funaki, I., Toki, K. and Kuriki, K.: Nonequilibrium Flow Analysis of a Two-Dimensional MPD Arcjet, IEPC-97-112, 1997.

6) Mikellides, P. G.: Modeling and Analysis of a MegawattClass Magnetoplasmadynamic Thruster, J. Propul. Power, 20 (2004), pp. 204-210.

7) Sato, H., Kubota, K. and Funaki, I.: Numerical Study on the Effects of Propellant Species in a Self-Field Magnetoplasmadynamic Arcjet, IEPC Proceeding, IEPC-2009-232, 2009.

8) Tahara, H., Yasui, H., Kagaya, Y. and Yoshikawa, T.: Experimental and Theoretical Researches on Arc Structure in a Self-Field Thruster, AIAA Paper 87-1093, 1987.

9) Kuchi-ishi, S. and Nishida, M.: Numerical Simulation of a Nonequilibrium Plasma Flow in a Nitrogen Arcjet Thruster Using a Three-Temperature Kinetic Model, IEPC-97-084, 1997.

10) Fujita, K. and Arakawa, Y.: Performance Computation of a Low-Power Hydrogen Arcjet, J. Propul. Power, 15 (1999), pp. $144-150$.

11) Kubota, K., Funaki, I. and Okuno, Y.: Numerical Study of Plasma Behavior in a Magnetoplasmadynamic Thruster around Critical Current, J. Propul. Power, 25 (2009), pp. 397-405.

12）佐藤博紀, 窪田健一, 船木一幸: 振動温度を考慮した水素 MPD アークジェットの電磁流体解析，第 54 回宇宙科学技術連合講演 会, $3 \mathrm{C} 04,2010$

13）中田大将，都木恭一郎，船木一幸，清水幸夫，國中 均，荒川義 博: $5 \mathrm{ch}$ 平行平板 MPD を用いた電極降下電圧の推定とその妥 当性について, 平成 19 年度宇宙輸送シンポジウム, 2008, pp. 435-438.

14）杵淵紀世志，船木一幸，都木恭一郎，清水幸夫： 2 次元型 MPD アークジェットの速度場と電力収支計測, 日本航空宇宙学会論文 集, 53 (2005), pp. 25-33.

15) Tahara, H., Kagaya, Y. and Yoshikawa, T.: Quasi-Steady MPD Arcjets with Applied Magnetic Fields, AIAA Paper 85-2001, 1985.

16) Gnoffo, P. A., Gupta, R. N. and Shinn, J. L.: Conservation Equations and Physical Models for Hypersonic Air Flows in Thermal and Chemical Nonequilibrium, NASA TP-2867, 1989.

17) Yos, J. M.: Transport Properties of Nitrogen, Hydrogen, Oxygen, and Air to $30,000^{\circ} \mathrm{K}, \mathrm{RAD}-\mathrm{TM}-63-7,1963$.

18) Stallcop, J. R., Levin, E. and Partridge, H.: Transport Properties of Hydrogen, J. Thermophys. Heat Transfer, 12 (1998), pp. $514-519$

19) Gupta, R. N., Yos, J. M., Thompson, R. A. and Lee, K. P.: A Review of Reaction Rates and Thermodynamic and Transport Properties for an 11-Species Air Model for Chemical and Thermal Nonequilibrium Calculations to $30000 \mathrm{~K}$, NASA RP-1232, 1990.
20) Sharma, S. P. and Schwenke, D. W.: Rate Parameters for Coupled Rotation-Vibration-Dissociation Phenomena in $\mathrm{H}_{2}$, J. Thermophys., 5 (1991), pp. 469-480.

21) Park, C.: Nonequilibrium Ionization and Radiation in Hydrogen-Helium Mixtures, AIAA Paper 2010-814, 2010.

付 録

A.1 輸送係数 ここでは, 各輸送係数の評価方法につ いて説明する．粘性係数以外の各評価式は文献 16) を参考 にしている。 なお，添え字の $i, j$ の番号は $0 \sim 3$ の範囲で, それぞれ $\mathrm{H}_{2}, \mathrm{H}, \mathrm{H}^{+}$, e を表す。

A.1.1 熱伝導係数 以下に並進温度, 回転温度, 振動温 度，電子温度それぞれの熱伝導係数 $\lambda_{\mathrm{tr}}, \lambda_{\mathrm{rot}}, \lambda_{\mathrm{vib}}, \lambda_{\mathrm{e}}$ の 評価式を示す。

$$
\begin{aligned}
& \lambda_{\mathrm{tr}}=\frac{15}{4} k \sum_{i=0}^{2} \frac{\gamma_{i}}{\sum_{j=0}^{2} a_{i j} \gamma_{j} \Delta_{i j}^{(2)}\left(T_{\mathrm{tr}}\right)+3.54 \gamma_{\mathrm{e}} \Delta_{i \mathrm{e}}^{(2)}\left(T_{\mathrm{e}}\right)} \\
& \lambda_{\mathrm{rot}}=k \frac{\gamma_{\mathrm{H}_{2}}}{\sum_{j=0}^{2} \gamma_{j} \Delta_{\mathrm{H}_{2}-j}^{(1)}\left(T_{\mathrm{tr}}\right)+\gamma_{\mathrm{e}} \Delta_{\mathrm{H}_{2}-\mathrm{e}}^{(1)}\left(T_{\mathrm{e}}\right)} \\
& \lambda_{\mathrm{vib}}=\lambda_{\mathrm{rot}} \\
& \lambda_{\mathrm{e}}=\frac{15}{4} k \frac{\gamma_{\mathrm{e}}}{\sum_{j=0}^{3} 1.45 \gamma_{j} \Delta_{\mathrm{ej}}^{(2)}\left(T_{\mathrm{e}}\right)}
\end{aligned}
$$

各式中の修正衝突積分 $\Delta_{i j}^{(1)}, \Delta_{i j}^{(2)}$ は以下の通り評価した.

$$
\begin{aligned}
& \Delta_{i j}^{(1)}\left(T_{s}\right)=\frac{8}{3}\left[\frac{2 m_{i} m_{j}}{\pi k T_{s}\left(m_{i}+m_{j}\right)}\right]^{1 / 2} \pi \bar{\Omega}_{i j}^{(1,1)} \\
& \Delta_{i j}^{(2)}\left(T_{s}\right)=\frac{16}{5}\left[\frac{2 m_{i} m_{j}}{\pi k T_{s}\left(m_{i}+m_{j}\right)}\right]^{1 / 2} \pi \bar{\Omega}_{i j}^{(2,2)}
\end{aligned}
$$

ここで下添え字 $s$ は t $\operatorname{tr}$ あいは $\mathrm{e}$ である。衝突積分 $\pi \Omega_{i, j}$ は温度の関数であり, 中性粒子との衝突によるものは文 献 17,18)を引用した。また，荷電粒子どうしの衝突積分 は文献 19)の Gvosgover cross section for Coulomb collisions から評価した。

A.1.2 粘性係数 粘性倸数 $\mu$ の評価式を以下に示す.

$$
\mu=\frac{\left(\lambda_{\mathrm{tr}}+\lambda_{\mathrm{rot}}\right) \operatorname{Pr}}{c_{p}}=\frac{\left(\lambda_{\mathrm{tr}}+\lambda_{\mathrm{rot}}\right) \operatorname{Pr}}{5 R_{\mathrm{H}} / 2}
$$

式中のプラントル数 $\operatorname{Pr}$ は $2 / 3$ とした.

A.1.3 導電率 導電率 $\sigma$ の評価式を以下に示す.

$$
\sigma=\frac{e^{2}}{k T_{\mathrm{e}}} \frac{\gamma_{\mathrm{e}}}{\sum_{i \neq \mathrm{e}} \gamma_{i} \Delta_{\mathrm{e} i}^{(1)}\left(T_{\mathrm{e}}\right)}
$$

A.2 解離·電離反応によるエネルギー増減 式 (4), (5) の解離反応によるエネルギーの増減は以下の式から求めら れる。

$$
Q_{\mathrm{diss}}^{\mathrm{h}}=\frac{1}{2} c e V_{\mathrm{diss}} \sum_{s=2}^{4} 2\left(k_{f} n_{\mathrm{H}_{2}}-k_{b} n_{\mathrm{H}} n_{\mathrm{H}}\right) n_{s}
$$

式中の係数 $c$ は解離モデルを選択する係数であり, 本解析 
では $c=1$ とした. 式 (6) 中の電子衝突による解離および 電離反応のエネルギー増減は以下のように評価する。

$$
\begin{aligned}
& Q_{\mathrm{diss}}^{\mathrm{e}}=\frac{1}{2} c e V_{\mathrm{diss}} 2\left(k_{f, 1} n_{\mathrm{H}_{2}} n_{\mathrm{e}}-k_{b, 1} n_{\mathrm{H}} n_{\mathrm{H}} n_{\mathrm{e}}\right) \\
& Q_{\mathrm{ion}}^{\mathrm{e}}=e V_{\mathrm{ion}} \frac{\dot{\rho}_{\mathrm{H}^{+}}}{m_{\mathrm{atom}}}
\end{aligned}
$$

各反応係数は, 以下の通り4,10) である. なお，温度 $T_{s}$ の 単位は $[\mathrm{K}]$ である. 完全解離した場合, $T_{\mathrm{vib}}$ は物理的な意 味を持たないため, $T_{\mathrm{vib}}=T_{\mathrm{tr}}$ として算出した.

$$
\begin{aligned}
k_{f 1}= & 7 \times 10^{-16} T_{\mathrm{e}}^{0.33} \exp \left(-103,900 / T_{\mathrm{e}}\right) \\
k_{f 2}= & k_{f 3} \\
= & k_{f 4} \\
= & 9.1 \times 10^{-12} \sqrt{T_{\mathrm{tr}} T_{\mathrm{vib}}}-1 \\
& \times \exp \left(-51,900 / \sqrt{T_{\mathrm{tr}} T_{\mathrm{vib}}}\right) \\
k_{f 5}= & 2.5 \times 10^{-17} T_{\mathrm{e}}^{0.57} \exp \left(-158,000 / T_{\mathrm{e}}\right) \\
k_{b 1}= & 2.8 \times 10^{-39} T_{\mathrm{e}}^{-1} \\
k_{b 2}= & k_{b 3}=k_{b 4}=5.0 \times 10^{-42}{\sqrt{T_{\mathrm{tr}} T_{\mathrm{vib}}}-1}^{-1} \\
k_{b 5}= & 1.09 \times 10^{-20} n_{\mathrm{e}}^{2} n_{i} T_{\mathrm{e}}^{-9 / 2}
\end{aligned}
$$

A.3 エネルギー緩和項 並進一振動エネルギーの緩和項 $Q_{\text {tr-vib }}$ は Millikan-White による式20) から評価する. 完全 解離の領域において $\rho_{\mathrm{H} 2}=0$ となるため, 振動エネルギー に関する緩和項はゼロとした。

$$
Q_{\mathrm{tr}-\mathrm{vib}}=\rho_{\mathrm{H}_{2}} \frac{e_{\mathrm{vib}}\left(T_{\mathrm{tr}}\right)-e_{\mathrm{vib}}\left(T_{\mathrm{vib}}\right)}{\tau_{\mathrm{tr}-\mathrm{vib}}}
$$

単位質量あたりの振動エネルギー $e_{\mathrm{vib}}$ と緩和時間 $\tau_{\mathrm{tr}-\mathrm{vib}}$ については，それぞれ以下のように評価する20).

$$
\begin{aligned}
& e_{\mathrm{vib}}\left(T_{s}\right)=\frac{R_{\mathrm{H}_{2}} \theta_{\mathrm{vib}}}{\exp \left(\theta_{\mathrm{vib}} / T_{s}\right)-1} \\
& \tau_{\text {tr-vib }}=\frac{1}{p[\mathrm{~atm}]} \exp \left[A\left(T_{\mathrm{tr}}^{-1 / 3}-0.015 \mu^{1 / 4}\right)-18.42\right]
\end{aligned}
$$

電子一振動エネルギーの緩和項 $Q_{\text {e-vib }}$ は以下のように評価 する. 式中の電子・振動間の緩和時間 $\tau_{\mathrm{e}-\mathrm{vib}}$ は文献 21$)$ か ら引用した。

$$
Q_{\mathrm{e}-\mathrm{vib}}=\rho_{\mathrm{H}_{2}} \frac{e_{\mathrm{vib}}\left(T_{\mathrm{e}}\right)-e_{\mathrm{vib}}\left(T_{\mathrm{vib}}\right)}{\tau_{\mathrm{e}-\mathrm{vib}}}
$$

並進-電子エネルギーの緩和項 $Q_{\mathrm{tr}-\mathrm{e}}$ は以下のように評 価する。

$$
Q_{\mathrm{tr}-\mathrm{e}}=3 \sum_{s=0}^{2} \frac{m_{\mathrm{e}} n_{\mathrm{e}}}{m_{s}} \nu_{\mathrm{e}-s} k\left(T_{\mathrm{tr}}-T_{\mathrm{e}}\right)
$$

本文中の電子-並進間のエネルギー緩和時間 $\tau_{\mathrm{tr}-\mathrm{e}}$ は以下の ように評価した。

$$
\tau_{\text {tr-e }}=\sum_{s=0}^{2} \frac{m_{s}}{2 m_{\mathrm{e}} \nu_{\mathrm{e}-s}}
$$

A.4 全エネルギーの保存則 式 (4) の重粒子エネルギー 保存則と式 (6)の電子エネルギー保存則を足し合わせると, 以下の式となる。これは全エネルギー保存則である.

$$
\begin{aligned}
\frac{\partial}{\partial t} & \left(E_{\mathrm{h}}+E_{\mathrm{e}}\right)+\nabla \cdot\left[\left(E_{\mathrm{h}}+E_{\mathrm{e}}+p\right) \boldsymbol{u}\right] \\
= & \boldsymbol{u} \cdot(\boldsymbol{j} \times \boldsymbol{B})+\frac{\boldsymbol{j}^{2}}{\sigma} \\
& +\nabla \cdot\left[\left(\lambda_{\mathrm{tr}}+\lambda_{\mathrm{rot}}\right) \nabla T_{\mathrm{tr}}+\lambda_{\mathrm{vib}} \nabla T_{\mathrm{vib}}+\lambda_{\mathrm{e}} \nabla T_{\mathrm{e}}\right] \\
& +\nabla \cdot(\tau \boldsymbol{u})-Q_{\mathrm{diss}}^{\mathrm{h}}-Q_{\mathrm{diss}}^{\mathrm{e}}-Q_{\mathrm{ion}}^{\mathrm{e}}
\end{aligned}
$$

